\title{
Assessment of the quality of canal water used for irrigation purpose in Muzaffarnagar district of Uttar Pradesh
}

\section{SUSHIL KUMAR, G. R. SINGH, H. K. YADAV AND PRAMOD KUMAR}

Received : 22.07.2017; Revised : 05.11.2017; Accepted : 15.11.2017

\section{MEMBERS OF RESEARCH FORUM:}

Corresponding author : SUSHIL KUMAR, Department of Soil Science and Agricultural Chemistry, C.C.R.D. College, MUZAFFARNAGAR (U.P.) INDIA

Co-authors :

G.R. SINGH, Department of Soil Science and Agricultural Chemistry, C.C.R.D. College, MUZAFFARNAGAR (U.P.) INDIA

H. K. YADAV, Department of Soil Science, Chaudhary Charan Singh Haryana Agricultural University, HISAR (HARYANA) INDIA

PRAMOD KUMAR, Krishi Vigyan Kendra, Baghra, MUZAFFARNAGAR (U.P.) INDIA

\section{Summary}

Water is the most important natural resource which needs to be properly and scientifically utilized for improving the productivity, environment and economic condition of the rural area. The present study was conducted to canal water quality status in district of Muzaffarnagar, Uttar Pradesh, for irrigation purpose. The canal water samples were analyzed for their chemical properties total salt (electrical conductivity), $\mathrm{pH}$, anions $\left(\mathrm{Cl}, \mathrm{HCO}_{3}, \mathrm{SO}_{4}, \mathrm{NO}_{3}, \mathrm{~F}, \mathrm{~B}\right)$, cations $\left(\mathrm{Ca}^{2+}+\mathrm{Mg}^{2+}, \mathrm{Na}^{+}, \mathrm{K}^{+}\right)$. In water samples total salt (EC) ranged from 0.20 to $0.64 \mathrm{dSm}^{-1}, \mathrm{pH} 7.2$ to 8.1, potassium 1.95 to $12.12 \mathrm{mg} \mathrm{L}^{-1}$, sodium 2.80 to $65.55 \mathrm{mg} \mathrm{L}^{-1}, \mathrm{Ca}+\mathrm{Mg} 22.80$ to $96.40 \mathrm{mg} \mathrm{L}^{-1}$, bicarbonate 82.96 to $269.01 \mathrm{mg} \mathrm{L}^{-1}$, chloride 12.60 to $44.38 \mathrm{mg} \mathrm{L}^{-1}$, sulphate 12.81 to $105.71 \mathrm{mg}$ $\mathrm{L}^{-1}$, nitrate 2.50 to $25.42 \mathrm{mg} \mathrm{L}^{-1}$, fluoride 0.21 to $0.86 \mathrm{mg} \mathrm{L}^{-1}$ and boron 0.10 to $3.51 \mathrm{mg} \mathrm{L}^{-1}$. Correlation was also works out between different parameters. The correlation co-efficient (r) among nine canal water quality parameter namely total salt (electrical conductivity), $\mathrm{pH}$, anions $\left(\mathrm{Cl}, \mathrm{HCO}_{3}, \mathrm{SO}_{4}, \mathrm{NO}_{3}, \mathrm{~F}, \mathrm{~B}\right)$, cations $\left(\mathrm{Ca}^{2+}+\mathrm{Mg}^{2+}, \mathrm{Na}^{+}, \mathrm{K}^{+}\right)$were calculated for correlation analysis which showed chemical facies of canal irrigation water samples. The EC showed good positive correlation with chloride, sulphate, $\mathrm{Ca}+\mathrm{Mg}$, nitrate, bicarbonate, potassium, sodium and negative correlation with $\mathrm{pH}$. The Muzaffarnagar district is safe for irrigation purpose.

Key words : Canal water analysis, Cations and anions, Correlation, Irrigation purpose

How to cite this article : Kumar, Sushil, Singh, G.R., Yadav, H.K. and Kumar, Pramod (2017). Assessment of the quality of canal water used for irrigation purpose in Muzaffarnagar district of Uttar Pradesh. Asian J. Soil Sci., 12 (2) : 257-264 : DOI : 10.15740/HAS/AJSS/12.2/257-264. 